\title{
'Earth conceal not my blood': forensic and archaeological approaches to locating the remains of Holocaust victims
}

\section{Caroline Sturdy Colls}

\section{Introduction}

'Earth conceal not my blood'. It is this statement with which every visitor to Sobibór in Poland was confronted as they entered the memorial site marking the former Nazi extermination camp that existed there from April 1942 to October 1943. ${ }^{1}$ This echoed the biblical statement in the Book of Job, in which Job pleads 'O earth, cover not thou my blood, and let my cry have no resting place.' Although this line has received different interpretations, one assumption is that Job is calling for justice; he believes that if blood is covered, murderers will not be called to account for the crimes they have perpetrated and innocent victims will be forgotten. At Sobibór, the statement seems to have been used in a similar way. Here we see the human body used as a means to ask visitors to remember the crimes committed there and to never forget those who perished during the Holocaust.

The perception of graves and corpses as evidence of Nazi crimes, and as proof of life, was not only a post-war phenomenon. During the Holocaust, attempts were made by victims and witnesses to alert the wider world to the crimes being perpetrated by burying or hiding physical evidence. For example, speaking about Treblinka extermination camp, survivor Abraham Goldfarb stated: 'we secretly placed in the walls of the graves whole skeletons and we wrote on scraps of paper what the Germans were doing at Treblinka ... if one 
day someone looked for the traces of the Nazis' crimes, they could indeed be found. ${ }^{3}$ Many testimonies like this one also suggest that the victims and witnesses of these atrocities expected searches for the victims to be carried out in the aftermath of conflict.

However, despite these sentiments, the earth continues to conceal the remains of those killed at places like Sobibór and Treblinka. Although the existence of post-war legal trials, historical enquiries and images in the media lead us to believe that the events of the Holocaust are well known, there have actually been very few investigations throughout Europe that have sought to locate burial sites and the remains of Holocaust victims in the years since the Second World War. Of those searches that have been undertaken, few have drawn upon techniques now commonly used by forensic practitioners and archaeologists during investigations of the recent and distant past. Additionally, many of those who have attempted to examine human remains of Holocaust victims have had limitations placed upon their work. ${ }^{4}$ Consequently, questions still remain about the fates of many victims and what exactly happened to their remains. Thousands of burial sites are still unlocated and unmarked.

This situation presents something of a paradox: why do corpses form a central part of Holocaust iconography and yet remain elusive in the physical sense? Why have large-scale searches for Holocaust victims not been carried out? How is it possible that the remains of so many people have not been found? How might we go about finding them in the future? Through the presentation of a case study from the author's own research, this chapter will consider these questions and highlight the challenges that archaeologists will likely face should they choose to investigate Holocaust sites in the future. It will be shown how, provided these challenges are addressed, it will be possible to locate previously unmarked sites, characterise burial environments, examine human remains and shed new light on practices of killing and body disposal.

\section{An evidence paradox}

Millions of people are known to have died during the Holocaust. The remains of some have been found, but the remains of the majority have not. Only a handful of investigations have been carried out at Holocaust sites by archaeologists, the majority in the last decade, but few have included the search for graves. ${ }^{5}$ For the most part, archaeologists have focused on recording the structural remains of the 
camps. Recent examples include work at Sobibór, Sachsenhausen, Mauthausen, Semlin, Westerbork, Amersfoort, Falstad and in the Channel Islands. Conversely, over the last forty years, forensic archaeologists and anthropologists have played a central role in investigations of crimes against humanity elsewhere in relation to the detection and analysis of clandestine burials and body deposition sites. Responses to genocide and mass violence in Argentina, the former Yugoslavia, Kosovo, Rwanda and Iraq in particular have seen the development of sophisticated search and recovery methodologies. ${ }^{6}$ The evidence collected and examined by forensic archaeologists and anthropologists has been used in court to ensure that perpetrators are held accountable and in a humanitarian context in order to satisfy the needs of families and friends of victims wishing to know the fate of their loved ones. Likewise, in some countries (such as the Netherlands, the United Kingdom and the United States), forensic archaeologists and anthropologists are now regularly employed to assist the police in the detection and recovery of clandestine burials in domestic missing persons cases. ${ }^{7}$ Therefore, well-established protocols now exist for investigations where victims' bodies have been disposed of illicitly.

There are a number of complex reasons why the response to the Holocaust has been quite different. Some relate to the attempts by the perpetrators to hide their crimes, others to the effects of time. These are discussed in more detail in the context of the case study provided below (see section 'Treblinka extermination and labour camps, Poland'). In general terms, when the various narratives of the Holocaust and the sensitivities that surround this period are examined, it becomes immediately clear that many of the reasons why large-scale searches for Holocaust victims have not been carried out relate to the ways in which corpses have been perceived by individuals, groups and societies. These key reasons will be summarised here in order to highlight some of the main challenges that archaeologists may face in the course of their work in the future. A comprehensive overview of these and other issues is also provided in the author's previous work. ${ }^{8}$

\section{Previous investigations}

The sheer scale of the crimes perpetrated by the Nazis is one reason why corpses came to form such a central part of Holocaust iconography, in that the landscape of Europe was literally littered with traces of mass violence both during and after the Second World War. 
Therefore, in some places, it was not deemed necessary to search for the remains of victims since many could easily be found. For example, in camps like Auschwitz-Birkenau, Bergen-Belsen, Ohrdruf and Dachau, the liberators were faced with thousands of bodies that had not been buried by the perpetrators and, as such, they were faced with the huge task of burying them. These burials were carried out quickly in light of the need to provide a suitable place to prevent the spread of disease and to limit the trauma faced by survivors. ${ }^{9}$ Throughout Germany in particular, it was common practice for perpetrators, people deemed to have an association with the Third Reich and local communities to be forced to bury the corpses. ${ }^{10}$ This took place at Dachau, Buchenwald, Nordhausen and Namering, and local people were forced to view the corpses, which were laid out in the camp grounds at the request of the American liberating forces. ${ }^{11}$ In many towns and villages, communities searched for the dead and funerary scenes were common sights in the places where the Nazis had carried out massacres of the local population. Some of these sites were marked but others were not.

The scale of the crimes perpetrated during the Holocaust is also a reason why relatively few searches have been carried out; the logistics and finance required to undertake such operations was beyond the capabilities of the nations involved at the time and has remained so since. Therefore, investigations undertaken after the war occurred for very specific reasons and the treatment of corpses thus varied depending on local circumstances.

At some sites, corpses were not being inhumed but rather exhumed in an attempt to document the Nazis' crimes. A number of medico-legal investigations were conducted in the immediate aftermath of liberation or after the end of the Second World War with the intention of locating mass graves and other body deposition sites. ${ }^{12}$ The majority of these investigations were focused on verification of the fact that graves existed rather than on their detailed investigation. At the extermination camps at Auschwitz-Birkenau, Sobibór, Bełżec, Chełmno and Treblinka, as well as at most individual killing sites across Europe, it appears (from post-war reports) that it was not the intention to locate all graves and full exhumations were not carried out. Searches were also not geared towards the identification of victims but rather documenting for the courts, so far as was necessary, evidence that a crime had occurred and what had happened at a particular place in general terms. The presence and condition of bodies began to be used in criminal tribunals such as Nuremberg in order to attest to the brutality of Nazi crimes. ${ }^{13}$ 
As time went on, in many places the perceptions of corpses also changed so that they went from being something that should be seen (for example, as a reminder and a form of evidence) to something that should be buried and remain undisturbed. Crime scenes became memorial spaces and lines were drawn under criminal investigations. This of course happened at different times throughout Europe, depending upon the political and social climate in any given country. In other places, the desire to search for the victims of the Holocaust never went away but was rather suppressed by politics or ongoing social tensions. ${ }^{14}$ Consequently, current attitudes towards human remains can sometimes be a reflection of the complex post-war histories and cultural memory connected to a site. ${ }^{15}$

In the years since the end of the Second World War, a few exhumations have taken place at Holocaust sites for the purpose of providing evidence in legal investigations. ${ }^{16}$ In some countries such as Germany and Poland - the crimes perpetrated during the Holocaust could still potentially become part of a legal investigation since the statute of limitations on the investigation of war crimes has not passed or does not exist. ${ }^{17}$ However, in recent years, human remains from Holocaust sites have been most commonly recovered when they have been discovered serendipitously (for example, in the course of building work) rather than as a result of proactive searches organised in either a legal or humanitarian context. ${ }^{18}$ Rarely have there been searches that have sought to exhume Holocaust victims for humanitarian reasons and rarely has it been possible to identify victims in the absence of ante-mortem information about missing persons. As the Holocaust continues to sit between history and memory - between a legal/forensic context and an archaeological one - it is likely that the role of corpses in searches and Holocaust narratives will continue to vary.

\section{Popular perceptions}

The deaths and disposals that occurred during the Holocaust resulted in very public and an abnormally high number of interactions between the dead and the living, both at the time and in its aftermath. Many of these interactions were consequently documented by witnesses or were photographed, filmed and broadcast by the media. ${ }^{19}$ Thus in addition to the materials generated during war crimes trials, after the war sources emerged that further illustrated the nature of the Nazis' crimes; hence, corpses became a central 
part of Holocaust iconography. In the secondary literature that followed, the gas chambers, the crematoria, mass graves and execution sites (as the places where these mass killings and body disposals occurred) have continued to be what defines the Holocaust in public consciousness. ${ }^{20}$

The prevalence of corpses in Holocaust narratives and the openness with which they were presented in the public realm has undoubtedly contributed to the limited number of investigations aimed at locating victims' remains and appears to have created the mistaken perception that everything is known about the Holocaust. In the author's experience, there is often the belief that the majority of victims have either been found or that the Nazis were successful in totally obliterating all traces of their crimes, and as such it is not possible to find victims' remains. ${ }^{21}$ However, neither is true and, as will be demonstrated later in this chapter, forensic and archaeological approaches have the potential to reveal a considerable amount of new evidence and locate body disposal sites.

\section{Sensitivities}

There are also many reasons why large-scale searches for the remains of Holocaust victims have not been carried out that relate to the sensitivities that have surrounded and continue to surround this period of history. It is unquestionable that corpses were symbols of suffering during the Holocaust and since. Although many communities engaged in prodigious searches, exhumations and reburials in the immediate post-war period, for many people, corpses became something to forget, something to cover up quickly and something that should remain buried, physically and metaphorically. Some people did not, and do not, want sites to be excavated because this would bring physical evidence to the fore that is deemed too painful - thus by default they are opposed to archaeological and forensic investigations that seek to recover remains. ${ }^{22}$ In some countries, politics, the potential for scandals around blame and collaboration, ongoing friction, anti-Semitism and marginalisation of minority groups offer just some of the possible explanations as to why searches have not been carried out. Some communities have not encouraged or supported investigations because they are content with the information they have about a particular place. When memorials already exist, some people may question why it is necessary to revisit these places, to disturb them and to revive painful memories. ${ }^{23}$ Elsewhere, it may 
be a failure to feel a connection to the history of the Holocaust that has resulted in a lack of interest in locating graves. ${ }^{24}$ Investigations of Holocaust sites have been carried out in other places as a way of confronting tensions that still remain and as a way of dealing with the past. ${ }^{25}$ In some cases, exhumations have deliberately or inadvertently led to the resurfacing of old rivalries (for example, in the former Yugoslavia).

\section{Religion}

Of all the reasons that have affected whether searches for corpses of Holocaust victims have been carried out, it is perhaps religion that has been the most influential. Exhumations were carried out in some places in the immediate aftermath of the Holocaust in order to provide victims with a proper burial, in accordance with their beliefs. Most commonly, this was undertaken in relation to the bodies of Christian victims. In the years since, when remains have been deemed to be under threat from natural or artificial landscape change, they have also been exhumed and reburied elsewhere, as in the case of a grave near Bełżec that was in danger of falling off a cliff and a recent case in Dobrzyn Nad Wisla, Poland, where human remains emerged on a riverbank as a result of erosion. ${ }^{26}$

However, the reason that the majority of Holocaust graves have not been exhumed or located relates to the fact that they contain the remains of Jewish victims. When a review of previous investigations is undertaken it becomes apparent that, in most cases, Jewish law (Halacha) has led to searches being forbidden, restricted or incomplete. ${ }^{27}$ Despite the complexities of Jewish law (see David Deutsch's chapter in this volume), in essence it stipulates that the body of a deceased person is tied to a soul and, therefore, to disturb a grave is to disturb a soul. ${ }^{28}$ There are certain exclusions to this rule, for example if remains are under threat or if they have been scattered rather than buried within a grave..$^{29}$ However, in the absence of suitable non-invasive methods in the past, the graves of millions of Jewish victims have remained unlocated. The scientific analysis of remains is also forbidden; thus in the absence of DNA and osteological analysis, Jewish victims cannot be identified. ${ }^{30}$ It should be noted though that different rabbinical authorities and Jewish communities have different opinions about the disturbance of human remains and so the degree of opposition to proposed excavations will vary in different countries and in relation to different sites. For 
example, exhumations of the remains of Jewish victims have been permitted in several cases in Austria and some rabbis have argued that mass graves of the Holocaust should be treated differently from other Jewish burials. ${ }^{31}$ Evidently, victims are on an unequal footing in terms of the potential to be found, identified and buried in a marked grave, even within the same religious group. Additionally, there have been temporal variations in the treatment of Jewish victims. For example, in the immediate aftermath of the Holocaust, rabbis in many countries interpreted Jewish law more liberally in order to facilitate the exhumation and reburial of corpses buried in mass graves, but as time passed there has been a greater consensus to let the dead rest where they lie.

Conflicting religious beliefs at the same site must also be considered. The Nazis murdered people from a variety of faiths and cultures and buried them within the same grave. Thousands of Roma and Sinti people were killed during the Holocaust but there have not been dedicated efforts to find their remains. This is likely due to the fact that many Roma and Sinti people believe that graves are something to be feared (as the dead have the potential to haunt these places) and so they believe they should be left undisturbed. ${ }^{32}$ Conversely, as already noted, there is a Christian belief in the right to a proper burial with appropriate funeral rites. ${ }^{33}$ Some nonOrthodox Jews believe that the remains of victims should be found and buried in accordance with Halachic law, while hidden messages from victims (as discussed above) indicate the same desire. It may be unclear whether victims actually practised the religion by which they were identified by the Nazis. Differentiating between corpses belonging to people from these various groups may also be difficult, if not impossible, when excavation is undertaken. Thus the result is a very complex situation with a number of different opinions potentially existing in relation to the same graves. ${ }^{34}$ In the past, these issues have caused a number of problems for archaeologists seeking to undertake exhumations and work has been opposed, prevented and criticised. Examples include the archaeological investigations at Bełżec extermination camp in Poland in the $1990 \mathrm{~s}^{35}$ and, more recently, at a killing site in Iąsi in Romania. ${ }^{36}$

\section{Addressing challenges}

In light of the above discussion, it would seem that there is something of a dichotomy between the investigation of the Holocaust 
and archaeology/forensic investigation. Standard archaeological methodologies, centred on excavation, may not always be appropriate and may not be permitted, depending on the context in which searches are proposed. Practitioners may find themselves facing opposition because of the perceptions of archaeological and forensic investigations. Religion and the law may be at odds. The fact that the Holocaust remains within living memory can make the investigation of the physical evidence extremely sensitive; thus even describing the remains as archaeological may be deemed offensive. Archaeologists in particular may also face the added challenge of trying to demonstrate why fieldwork is necessary and what it may reveal, because of the aforementioned popular perceptions that human remains will not survive.

However, archaeological and forensic searches can be undertaken effectively provided these issues and sensitivities are taken into consideration. This is illustrated below through a case study from the author's own research.

\section{Treblinka extermination and labour camps, Poland}

\section{Historical background}

In an area of remote forest, north-east of Warsaw in Poland, there now exists the Museum of Struggle and Martyrdom in Treblinka and an accompanying memorial site that commemorates the Nazi extermination and labour camps that existed there. The camps claimed the lives of between 800,000 and 1,000,000 people mostly Jews through a combination of systematic murder (carried out at the extermination camp and at an execution site where people from the labour camp were routinely shot), death through work and poor living conditions. ${ }^{37}$ The extermination camp was only open for thirteen months, between the end of July 1942 and August 1943, but here a complex of gas chambers, killing sites, mass graves and cremation pyres was developed in order to efficiently 'process' victims in an industrialised fashion. ${ }^{38}$ Although in reality the camp was chaotic, people could be taken from the reception area of the camp and killed in the gas chambers within fifteen minutes. ${ }^{39}$ The story of the labour camp is less well known but a combination of poor living conditions, forced labour and executions resulted in the deaths of around 10,000 victims, including Polish political prisoners, Jews and Roma and Sinti..$^{40}$ This camp was located approximately $2 \mathrm{~km}$ south of the 


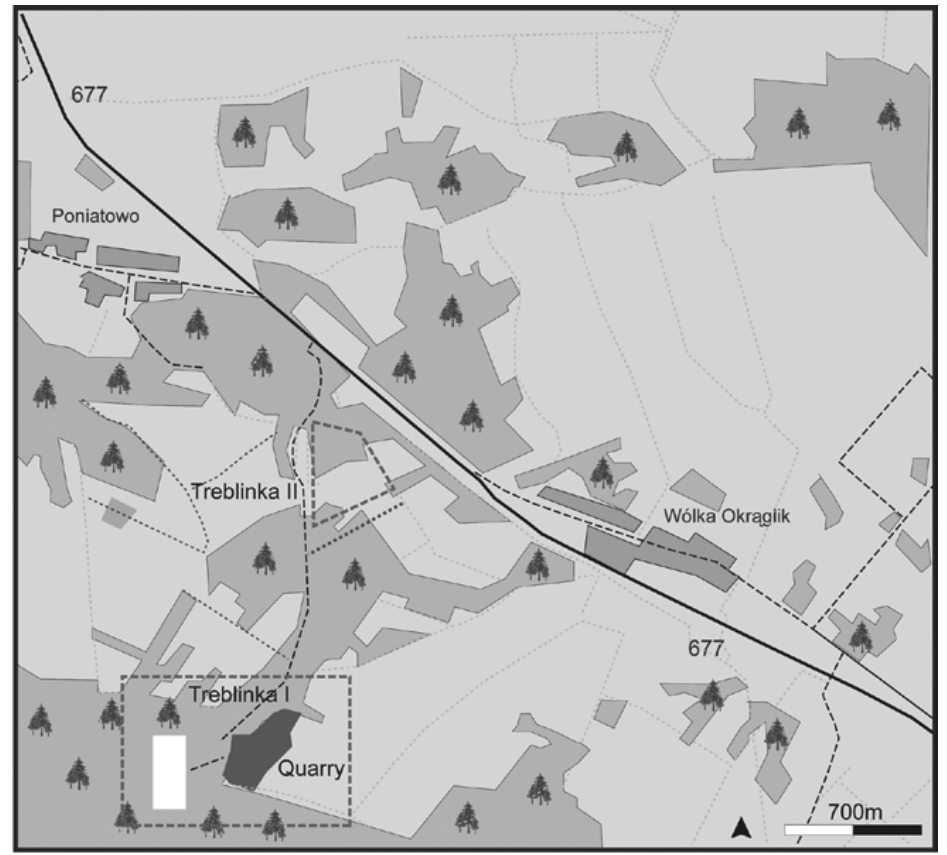

Figure 7.1 Location of the extermination and labour camps at Treblinka

extermination camp (Figure 7.1). The survival rate in both camps was very low and, as a result, only a small body of historical evidence attests to the crimes perpetrated. In 2007, when archaeological and historical research was initiated, a number of key questions still remained concerning the layout of the camps and the whereabouts of the bodies of the victims killed there.

\section{Methodological challenges}

Despite the scale and significance of the crimes perpetrated at Treblinka, the former camp area had not been examined since the mid-1940s. Even then, the investigation that took place was only cursory; the examination of the extermination and labour camps (which cover an area of approximately $4 \mathrm{~km}^{2}$ ) by a Polish investigative team lasted only five days. ${ }^{41}$ Shallow excavations were carried out in a small number of areas and, although human remains and other evidence were observed, they were not thoroughly examined. The remains found were disarticulated, scattered and dismissed as 
insignificant. Soviet investigations were equally brief. As a result, the common perception is that the Nazis succeeded in completely obliterating all traces of their crimes in Treblinka. ${ }^{42}$

Therefore, prior to commencing a new programme of forensic and archaeological research at Treblinka, it was important to consider why no further searches had been carried out for over sixty years. It was also necessary to consider how the site had changed in the years since and what issues needed to be borne in mind when designing and implementing fieldwork methodologies. The key issues are discussed below. Although they are presented here in the context of the work undertaken at Treblinka, in the author's experience they are relevant to the investigation of other Holocaust sites. Likewise the issues discussed in the section above were also central considerations during the work here.

\section{Landscape change and current site appearance}

The landscape of the former camps at Treblinka is vast (approximately $4 \mathrm{~km}^{2}$ ) and there were no adequate wartime plans of the area. The extermination camp was abandoned by the Nazis in 1943 (almost two years before the camp was liberated), and it was not protected until it was levelled to create a memorial in the 1960s. No obvious visible remains survive above the ground. By contrast, at the labour camp the foundations of the majority of the structures survive above the ground and some mass graves are marked (see below). Trees have been planted across much of the former extermination and labour camp areas in the years since the war, thus preventing the use of certain survey techniques (see section titled 'Developing a unique approach', below). Both sites have also been subject to looting since the end of the war by people looking for valuable personal effects. When examining sites like Treblinka, it is important to evaluate and document the physical changes that have accompanied the different phases of use in order to select appropriate search techniques and in order to distinguish between contemporary and more recent disturbances.

\section{Post-war investigations}

As noted above, a limited number of investigations took place at Treblinka in the post-war period and it became apparent through the author's research that there was, therefore, a belief that all evidence had been already found. ${ }^{43}$ This trend has been observed by the 
author at other Holocaust sites throughout Europe where post-war investigations were carried out. Similarly, as noted above, post-war investigators were often dismissive of certain types of evidence: for example, foundations, wooden posts, fences and scattered objects. This has led to a number of popular perceptions concerning the apparent absence of mass graves within the extermination camp area. It simply would not have been possible for the post-war investigators to have fully examined the site in the short amount of time they spent there. At the execution site close to the labour camp, forty mass graves were reportedly examined by the investigators, but the accuracy of their observations is unclear. It was also apparent from an examination of the investigators' reports that the bodies were not subject to detailed forms of analysis and it was not clear whether all graves had been found.

It is of course easy to be judgemental of the approach taken by this team. However, the Holocaust was unprecedented, as were the legal proceedings that followed, and there were no advanced methods available at that time for the examination of large numbers of corpses or the environment in which they were located. The fact that the remains at Treblinka have not been disturbed by further investigations in the last seventy years actually implies that a considerable amount of evidence would have survived that could be examined using the advanced methods now available to forensic archaeologists and anthropologists.

\section{Religious beliefs}

Jews, Christians and Roma and Sinti (of different faiths) were all killed at Treblinka. Historical research indicates that the majority of victims killed in the extermination camp were Jews from all over Europe, while both Polish Catholics and Jews were killed in the labour camp. The same research also revealed that unidentified mass graves and scattered remains were likely to exist at both sites. Therefore, all of these different religious beliefs needed to be taken into account when deciding how to search for the remains of the victims. It was immediately apparent that different approaches were needed for each area since these different groups have different opinions on death and burial. ${ }^{44}$ Consultations were initiated with religious leaders, the museum authorities, the Conservator of Monuments for the region and the Institute of National Remembrance in Warsaw. The Jewish community did not want the mass graves at the extermination camp to be disturbed and so it was agreed that no excavation 
would be undertaken in these areas. However, the Chief Rabbi of Poland, drawing on advice from others and Jewish law, decided that the recovery and reburial of scattered remains located in the course of excavations of structural remains would be permitted. There was also a consensus among the parties that the mass graves at the labour camp should be located via minimally invasive excavations but that the remains should be left in situ. This was consistent with the approach taken with regard to the marked mass graves that were examined after the war.

\section{Common perceptions}

A number of popular perceptions existed in relation to Treblinka with regard to the ways in which the Nazis attempted to hide their crimes, the conditions of the corpses and the destruction of the physical evidence in the post-war years. In summary, many publications (academic and in the popular press) state that very little physical evidence survived..$^{45}$ Thus some people (historians in particular) were initially sceptical about the value of carrying out archaeological investigations.

However, to assume that all traces of corpses were removed at a site without thorough research and in-field investigation is to overlook the complex nature of Nazi body disposal practices. A significant amount of evidence exists that demonstrates that not all of the corpses of Holocaust victims were treated in the same way. This issue has been discussed at length elsewhere: in short, very few of the practices employed to destroy the traces of corpses would have resulted in their complete destruction. ${ }^{46}$ For example, the majority of Holocaust victims across Europe were buried in mass graves, a practice that continued even after the order was given to exhume and cremate bodies. ${ }^{47}$ Similarly, upon the cremation of bodies, very few corpses would have been reduced to ashes and, as such, these remains may still be detectable. ${ }^{4}$ This was demonstrated during archaeological work at Bełżec and a considerable body of evidence existed prior to archaeological work at Treblinka suggesting that this was also the case there. ${ }^{49}$

\section{Condition of the remains}

When historical research was undertaken by the author, although it became apparent that the aforementioned popular perceptions were likely inaccurate, it was evident that the Nazis had gone to great 
lengths to hide the evidence of their crimes. ${ }^{50}$ It was noted that while some of the victims were buried in mass graves, others were cremated. Some cremated remains were reportedly also buried in pits while others were scattered across the fields. Some of the remains of victims initially buried in mass graves were also reportedly exhumed and burnt. It was therefore anticipated that the remains of the victims may be very difficult to find and that different approaches would be required in order to detect the various types of interments.

\section{Stakeholders}

As noted above, before work at Treblinka could proceed, formal permissions needed to be obtained from religious leaders, the museum authorities and the Conservator of Monuments. A consensus among all parties was also required. Through regular communication and open discussion, acquisition of these permissions was a relatively smooth, albeit lengthy, process. Granting of permission was subject to a commitment on the part of the archaeological team to carry out the work according to a pre-agreed methodology and reporting schedule with ethical standards and timescales.

\section{Developing a unique approach}

As a result of these issues, the landscape of Treblinka could not simply be examined using a conventional archaeological approach. The unique nature of the physical evidence at the site and the political, religious and ethical considerations that surround it meant that an equally unique approach was required for its investigation. This was particularly true of the human remains that were thought to be present and which had remained hidden for almost seventy years.

A variety of techniques are now available that offer the possibility to take a much broader approach to the analysis of landscapes of the Holocaust, and many of these techniques were employed at Treblinka between 2010 and 2015 by a team under the direction of the author. ${ }^{51}$ Through a combination of desk-based research and infield survey, it was possible to locate and characterise burial sites and the context in which they lie. By reviewing witness testimonies and documentary and photographic evidence and drawings, it was possible to re-evaluate the location and form of mass and individual graves, and the killing sites to which they relate. Primary witness interviews were undertaken where possible and this elicited information of direct relevance to the search for human remains, some 
of which had not previously been recalled by survivors. The detailed examination of historical maps, dating from before graves were dug through to the present day, helped build site histories. This assisted in the identification of possible burial locations and highlighted how the landscape had been modified over time. ${ }^{52}$ This was accompanied by similar regressions of aerial and satellite imagery.

Moving on to in-field investigation, other forms of remote sensing techniques proved fruitful. A drone survey was undertaken that captured up-to-date images from the air. ${ }^{53}$ A LiDAR survey was also carried out. This technique emits multiple laser pulses from a laser scanner mounted on an aircraft, and the return of these pulses can be measured in order to determine the elevations of the ground, structures, vegetation and anything else with which they come into contact. ${ }^{54}$ This elevation data can then be used to produce three-dimensional digital terrain models, and tree and vegetation cover can be removed from the image, revealing a site's bare earth. Vegetation change and other evidence of ground disturbance, such as depressions and mounds, indicative of buried remains can then be observed. As graves often exhibit such indicators a long time after creation, detecting these changes can be extremely useful; this has been proven repeatedly in a forensic context and now also at Treblinka. ${ }^{55}$ Recent developments in forensic archaeology also provided new ways of examining graves in terms of what they can reveal about offender behaviour and processes of inhumation. ${ }^{56}$ Even without excavation, it was possible to access these because the overall length, width and shape of the graves was recorded during the LiDAR survey and using a combination of other measured survey methods such as Differential Kinematic GPS and Total Station survey. ${ }^{57}$

In order to establish the depth, geophysical survey methods were required. ${ }^{58}$ There are a number of geophysical survey methods available that measure different properties of the soil and materials buried within it, highlighting the contrast between them and any signs of ground disturbance. The most common methods used in archaeological surveys are Ground Penetrating Radar (GPR), resistance survey and magnetometry. These techniques do not find 'bodies' but rather 'anomalies'. Therefore, the results generated must be compared to information derived from desk-based and other in-field research to determine whether the 'anomalies' suggest the presence of a grave. ${ }^{59}$ It is important to remember that corpses and graves of Holocaust victims will survive in different forms depending upon how victims were treated by perpetrators. These different 
conditions will sometimes require different techniques to be used to detect the remains and will offer different possibilities for investigation and discovery. For example, the use of magnetometry may be more appropriate if victims are thought to have been cremated and then reinterred in a collective grave because the technique detects evidence of burning and changes to the earth's magnetic field. ${ }^{60}$ Resistance survey provides a rapid tool when it is suspected that remains are buried at a shallow depth (usually less than one metre), while GPR provides an invaluable tool for examining deeper remains and viewing them in three dimensions ${ }^{61}$ All of these tools have limitations that should be considered on a case-by-case basis and, as such, GPR and resistance survey were employed at Treblinka. ${ }^{62}$ The data derived from these methods were layered onto and compared with other material collected during desk-based research and field survey in a Geographical Information Systems (GIS) in order to assist in determining the exact nature of any anomalies recorded. ${ }^{63}$

Minimally invasive excavations were carried out at Treblinka at mass graves at the execution site as it was not possible to carry out geophysical survey in these areas due to the density of the tree cover. Well-defined protocols for the recovery, storage and analysis of human remains were drawn upon from the disciplines of archaeology and forensic investigation during this work. Even though the work was not undertaken in a legal context, it was deemed important to follow recognised standards in order to ensure that remains were handled ethically and examined comprehensively. ${ }^{64}$ Similarly, well-established guidance also exists for the identification of victims and the assessment of remains to establish a biological profile such as the age, sex and pathologies of a victim. ${ }^{65}$ If these techniques are permitted, it may be possible to identify individuals, return their remains to their families and to ensure that they receive a proper burial. However, this type of analysis was not permitted at Treblinka since the excavations were only confirmatory. Although the discussion above outlines why investigations of Jewish victims will rarely involve the identification of victims, one aspect of Jewish law that has not been widely discussed in literature concerning missing persons investigations is the fact that to recover the remains of victims who have never been buried in a grave - scattered remains, for example - is considered to be an act of kindness. Therefore, archaeologists and forensic investigators may have a key role to play with regard to the recovery of these victims' remains. By drawing on search strategies developed in policing, forensic archaeology and forensic anthropology, it was 
possible to recover scattered remains at Treblinka (found during excavations of the gas chambers) and to work with the religious authorities to ensure that they were reinterred appropriately.

Instead of relying solely on one method or one disciplinary approach, archaeologists and other practitioners searching for graves should consider taking an interdisciplinary approach that draws on a variety of techniques, as carried out at Treblinka. These techniques offered the possibility to locate graves without excavation, thus accounting for the sensitivities surrounding individual sites and events and facilitating searches of a large, complex landscape. By using non-invasive methods, access may be provided to sites that have previously been 'off limits', thus facilitating the identification of burial sites for the first time. For example, searches for the remains of Jewish victims buried within graves became a possibility when non-invasive methods were adopted. ${ }^{66}$ Alternatively, if excavations are to be carried out then an awareness of the sensitivities surrounding this approach is essential.

Archaeological investigations can also have a key role to play in facilitating commemoration, enhancing historical narratives, informing conservation and developing educational tools. A range of new techniques and approaches that can be borrowed from other disciplines, such as the digital humanities, computer science and heritage management, formed a key part of the methodology employed at Treblinka and have also offered new opportunities to present information about the missing from the Holocaust. E-platforms, performances, exhibitions, artistic installations, public presentations and the media offer just some possibilities to communicate victims' stories with the wider public. The ability to combine testimonies, images, objects, field survey data and other sources within these forms of dissemination offer the possibility to return the identities to missing victims. In the absence of a body or a known/marked grave, these methods may play a particularly important role in raising awareness of individual and collective experiences, provided this material is presented in a sensitive and ethical manner ('Restoring identities' section, below).

\section{Treblinka’s hidden evidence}

By adopting the unique methodology employed at Treblinka, archaeological research has facilitated, and continues to facilitate, a detailed analysis of the entire landscape of the two camps and 
surrounding area. A summary of the findings directly related to the remains of the victims is provided below and the reader is referred to previous work for details on additional findings. ${ }^{67}$

With regard to the extermination camp, this non-invasive approach allowed the locations of several mass graves to be identified without disturbing the remains contained within them; thus Jewish law was adhered to, the memorial site remained undisturbed and the graves can be protected for the future. In total, eleven possible mass graves were recorded in the grassed areas surrounding the memorial at the extermination camp. Desk-based research indicated that it is likely that further graves exist under the monument. By examining the spatial distribution of these graves in relation to the structures, boundaries and other features that were identified using non-invasive survey methods, it was possible to identify the body disposal patterns and the ways in which the living and dead were moved through the extermination camp area. Permission was then granted to excavate in the areas where structures were thought to be present, provided the graves were avoided. Scattered human remains were found, mixed in with the demolition rubble of the gas chambers. Given that the majority of victims murdered in the extermination camp were Jewish, it is highly likely that at least the majority of these remains belonged to Jewish victims. However, the possibility that they belonged to Roma and Sinti victims could not be ruled out. Following consultation with the religious authorities and site custodians, the remains were recovered and reburied in a protected grave. This approach ensured that they were afforded a dignified burial for the first time in such a way that respected Jewish customs and those of other faith groups.

The combined use of archival research, LiDAR survey and walkover survey allowed at least six potential graves to be identified in the area of the execution site to the south of the labour camp. ${ }^{68}$ Permission was granted for minimally invasive excavations at three of these sites. Here an approach was adopted that involved stripping the turf and topsoil away from the areas indicated in the LiDAR survey and digging small, minimally invasive test trenches at strategic locations within each feature. This approach was developed as a result of discussions with the museum, religious and archaeological authorities, and by drawing on the author's expertise as a forensic archaeologist. As victims from multiple faith groups may have been present, and given that the aim of the excavation was to confirm that human remains were present so that the grave could be marked, this minimally invasive approach was deemed most appropriate. It 
was also carried out in such a way that it would be possible to go back to each site to conduct a full exhumation in the future if this was deemed necessary. The excavations revealed the presence of disarticulated human remains belonging to multiple individuals in all three areas. Shoes and bullets were also recovered. The human remains were reinterred into the graves. As a result of this work, the museum authorities immediately erected markers on these three graves, which have already become the focus of commemorative activities at the site. This represents the first time that these graves have been marked and the first time since the post-war investigations that unmarked graves have been found and examined.

This multifaceted approach was well received by the various groups with a connection to Treblinka as an appropriate compromise. It allowed the religious, ethical and scientific requirements of the research to be adequately balanced, without limiting the possibilities for further work in the future if it is desired.

\section{Future challenges}

One of the key questions that emerges from this chapter is: what contribution of knowledge can archaeologists realistically expect to make about the Holocaust seventy years after the events? It is hoped that the findings at Treblinka thus far demonstrate that archaeologists can make a significant contribution. The ability to locate previously unmarked graves and to find and recover the remains of victims so that they can have a marked burial means that archaeology offers the potential to provide information to victims' families and to provide new insights into the crimes committed during this period. The continued development of novel forensic and archaeological methods suggest that archaeologists will be able to make significant contributions in the future, even when excavation is not permitted.

However, the archaeological investigation at Treblinka highlighted a number of key issues and raised a number of further questions in relation to both the history of the site itself and the contribution that archaeologists can make to the examination of Holocaust sites more broadly. There are also several questions that archaeologists will not be able to answer and a number of further challenges that they will likely face in the future as a result, either because we are unable to excavate or because of the Nazis' attempts to hide their crimes. 


\section{Where are the bodies?}

In 2010, Richard Wright considered the question 'where are the bodies?' in relation to genocide in the twentieth and twenty-first centuries. ${ }^{69}$ This is a question that is often asked in relation to the Holocaust, sometimes by the relatives of those who were killed, sometimes by inquisitive individuals, but also, more commonly, by those who deny that the Nazis carried out mass murder. ${ }^{70}$ Certainly this question has been repeatedly posed in relation to Treblinka and it was one of the main aims of the archaeological research to attempt to answer it. The working answer devised by author is that, in some cases, we simply do not know where the bodies are and perhaps we never will. However, in other cases Wright's eloquent answer to his own question - 'in the ground' - can equally be provided.

By way of an example: Archaeological research at Treblinka has proven through the analysis of physical evidence that the remains of many of the victims do survive. Historical research has also shown that other remains may be 'in the ground' but they may be inaccessible, hidden or destroyed. In-field investigation demonstrated that the extermination camp at Treblinka should be considered as a cemetery, since human remains appear to be scattered and buried across much of it. During the non-invasive research, a combination of archival research, aerial imagery analysis, field survey and geophysical prospection has confirmed that mass graves do survive. Walkover survey and excavations around the structures at Treblinka then also revealed the presence of scattered human remains. Additionally, during reinterment of these remains, well away from the area where the victims were killed, further fragmented remains were unearthed.

The discovery of these remains, archival research and the accounts of post-war investigators demonstrate that, despite the assertion in much of the popular literature that the majority of the victims at Treblinka were cremated and reduced to ash, victims were disposed of in a variety of other ways. ${ }^{71}$ These include incomplete cremation and reinterment in existing graves, burial in mass graves, the scattering of disarticulated remains and the deposition of remains on the surface. These methods differed during the lifetime of the extermination camp, whereas at the labour camp mass burial appears to have remained a consistent method of disposal throughout the camp's period of operation. At the labour camp, the bodies of the victims were buried in mass graves, as shown by the exhumations that were carried out in the immediate post-war period. These investigations were only brief and, thus, the remains were not examined 
comprehensively. If these graves were re-examined it is highly likely that considerably more bodies would be found. Similarly, the recent archaeological work at the execution site has confirmed that three other mass graves exist that, in the absence of techniques such as LiDAR in previous years, had simply not been detected. A further three potential mass graves were also identified and these will be investigated in future field seasons.

Across much of the extermination camp, it is known or suspected that the bodies are 'in the ground', but the sheer number of remains and their scattered nature means that it would be a huge task to recover every fragment of every body. One need only look at the costs involved in recent mass grave investigations and mass disaster recoveries, which run into the hundreds of millions of dollars, to understand why this has rarely been undertaken at sites like Treblinka. ${ }^{72}$ The measures taken by the Nazis to hide their crimes only add to this problem. There is clear evidence that bodies were buried in the woods and covered with trees or dense vegetation, while others were reported to have been buried outside the camp area. Historical sources demonstrate that the remains of others were scattered on the surrounding fields following the cremation process. It would be impossible to recover the remains of all these victims since many will have been destroyed or damaged by years of ploughing and other forms of landscape change.

Similarly diverse body disposal methods are likely to exist and vary at other Holocaust sites across Europe. Archaeologists have to be realistic about the extent to which they can contribute to discussions about the numbers of victims. In light of the above discussion, archaeologists should not try to make such estimates but rather they should explain which remains it is/has been possible to locate and which it is/has not. The fact that it is not possible to locate remains says something in itself about attempts by the perpetrators to hide their crimes, issues such as landscape change and current limitations of detection equipment, all of which should be clearly outlined by archaeologists engaged in such searches.

\section{Restoring Identities}

One of the key issues during the Treblinka project was ensuring that the victims of the camp do not remain anonymous when it is not possible to exhume and/or examine their bodies in detail. Several solutions have been developed to account for this that are worthy 
of consideration here given that such issues will likely arise in the course of investigations at Holocaust sites in the future.

During the small-scale excavations carried out at the execution site at Treblinka, although the remains could not be fully exhumed, they were still thoroughly documented. This meant that it was possible to provide information about the victims whose remains were found; details like the sex, age, stature, trauma and pathologies of victims were derived in the field and retrospectively from the analysis of the detailed written and photographic record compiled. The configuration of remains within the graves, the shoes and the overall construction of the graves make it possible to say something about the experiences of the victims even if they cannot be identified by name. $^{73}$

Even though it may be preferable to identify individuals for a wide range of reasons, when this is not possible, this does not mean that unidentified bodies and items do not have a role to play in enhancing our understanding of the crimes perpetrated by the Nazis. When it is not permitted or possible to identify individual bodies, objects may take the place of corpses in providing 'names and faces' of missing people. ${ }^{74}$ This may be directly, through the location of objects that bear names, or indirectly, through the discovery of items that can be linked to individuals via other means such as the analysis of testimony and photographs. The excavations that were permitted at Treblinka in the terrain of the gas chambers resulted in the recovery of personal belongings including hair clips and jewellery. These items, alongside the scattered remains, dentures, teeth and other items that were recovered, provided the only evidence of individual and collective experiences in the absence of complete corpses. Through detailed research, including the analysis of witness testimonies, it has been possible to highlight some of these experiences and to explore some of the actions of the perpetrators.

The anonymity of corpses and objects can also play an important role in genocide education and prevention as this demonstrates the ways in which the Nazis successfully deprived people of their identity. Anonymous items can also reveal basic human desires; for example, the jewellery found close to the gas chambers at Treblinka demonstrates the will of people to keep precious items with them, even when they risked injury and death in order to do so (see Figure 7.2). Individual items and unidentified bodies also represent man's inhumanity to man. The overall form and locations of graves, as derived from non-invasive or invasive methods, can also yield 


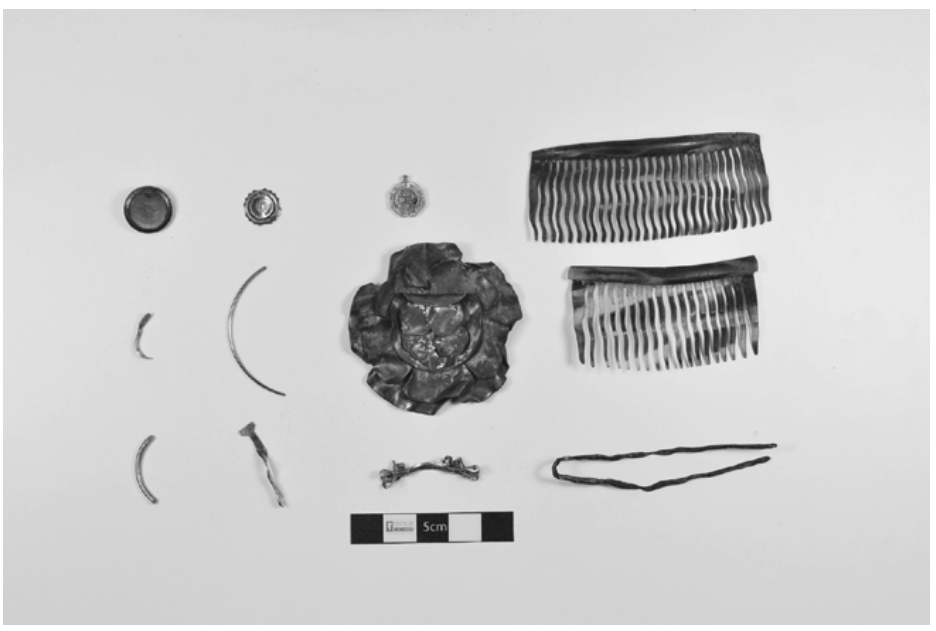

Figure 7.2 Some of the personal items unearthed during excavations in the area of the Old Gas Chambers at Treblinka that survive as a testament to the individuals who were sent there

important information about the ways in which people were disposed, 'offender behaviour' and attitudes towards these places in the past. For example, at both the extermination camp and execution site, non-invasive methods provided the dimensions of several mass graves and it was possible to plot their distribution and examine spatial relationships between the graves, structures and the movement of people.

The development of a number of dissemination tools that have sought to unite witness testimonies, photographs, archaeological survey data, video evidence, documentary records and other types of material identified during historical and archaeological research have provided different ways of ensuring that the physical evidence can be viewed alongside the stories of those who experienced Treblinka. One example is a combined exhibition and virtual archive that has sought to re-present the history of Treblinka through stories, images artwork and research findings. The aim of this combined approach is to provide greater access to a local and global audience. The production of different types of publications about the work, media appearances and outreach activities have also been undertaken to ensure broad dissemination of the findings to people with a wide range of backgrounds and prior knowledge of the camps. 
All of these approaches have sought to account for the sensitivities that surround Treblinka, make amends for the lack of investigation of the site in the past and provide new insights into the history of this brutal landscape. The project has sought to examine the events of the past, while paying attention to the enormous contemporary relevance of the work.

\section{Where next?}

The investigation at Treblinka is far from complete. Work will continue at the site for the foreseeable future and undoubtedly new questions and challenges will emerge. Likewise, Holocaust archaeology as a field of investigation is also on the rise. As part of future investigations, it is important to consider how corpses can be found and if they should be found, how they should be treated once they are located and what role they will play in commemoration and reconnecting identities. Knowing the potential options for identifying victims of violence (due to advances in forensic techniques), but being unable to do it at Treblinka, means the work can sometimes be frustrating, although there are clear reasons why this is the case. This will likely be a frustration shared by colleagues working at Holocaust sites in the future and by members of the public. Therefore, it is important for this reason to examine exactly why limitations are placed upon investigations and if decisions to prevent excavation are justified on ethical or religious grounds. At Treblinka, ethical questions also persist about whether or not the mass graves at the execution site should be fully exhumed and attempts made to identify individuals. As new research is emerging regarding the proportion of Polish victims and Jewish victims killed at this site, questions also need to be aired concerning whether or not excavations should be carried out, and whose opinion on this should influence methodologies.

The inability to exhume the corpses of all of the victims means that we will only ever have part of Treblinka's story, and there are questions that will most likely never be answered in the absence of human remains. There are some questions that we are not able to answer at this moment in time but, equally, there is the possibility that political and social tides will change in favour of excavation or that new technologies that will emerge that may facilitate more detailed investigations of graves. As a result, it is necessary to continually reflect on the methodologies employed at Treblinka 
and respond to these changing circumstances. Just as there is no single methodology that will work at every Holocaust site (because of the specific historical and ethical circumstances), methodologies employed at individual sites should also be multifaceted and flexible.

As a final point, for as long as victims' remains stay buried, Holocaust denial debates will undoubtedly continue to focus on the apparent absence of corpses as evidence that the Nazis did not commit the crimes indicated by the historical record and witness accounts. These are issues that we, as archaeologists and other specialists searching for information about these historic crimes, should expect to face. Yet, they are also issues that should be discussed with a wider audience more clearly alongside the presentation of the information that we are able to uncover. These challenges are not unique to Treblinka and will likely be encountered by anyone engaged in searches for human remains and the investigation of Holocaust landscapes.

\section{Conclusion}

Corpses of Holocaust victims remain something of a paradox. Given the ways in which they are remembered and forgotten, present and absent, lost and found, human remains assume a particular role in Holocaust iconography and collective memory. Searches in the past have been either motivated or limited by the complexities and sensitivities that surround the examination of corpses from this period. Archaeologists in particular have found themselves in difficult situations when attempting to search for, recover and re-present both the material remains of victims and the history to which they relate.

Corpses of Holocaust victims have taken on different meanings in the years since the end of the Second World War, many of which have resulted in restrictions being placed upon the work of those who seek to find them. It was the intention of this chapter to illustrate how these different meanings and interpretations of the past have influenced searches and to offer some new approaches for the future. This review has far from covered all of the complexities involved in searches for missing persons, but it is hoped that it will inspire further discussions among archaeologists, historians, anthropologists, legal professionals, religious groups, the public and other stakeholders concerning the complex range of ethical issues that have to be considered when addressing historic crimes. For whatever the 
reason searches are carried out, archaeologists and other professionals are certainly in a better position than ever before to shed new light on the crimes perpetrated during the Holocaust and should rise to the challenge of addressing the ethical issues that will arise when attempting to do so. There now exists a range of methods to search for human remains, allowing for a broader understanding of the landscapes and physical evidence of mass violence to be gained. By taking an interdisciplinary approach towards the investigation of mass and individual burials of Holocaust victims in the future, it is possible to ensure that, while corpses may continue to remain out of sight, they are not out of mind.

\section{Notes}

1 The memorial at Sobibór was redeveloped in 2014 and this memorial stone has now been removed.

2 Job, 16:18.

3 Y. Arad, Betzec, Sobibor and Treblinka: The Operation Reinhard Death Camps (Bloomington and Indianapolis: Indiana University Press, 1999), p. 176.

4 C. Sturdy Colls, Holocaust Archaeologies: Approaches and Future Directions (New York: Springer, 2015), ch. 2; despite the extensive archaeological investigations that have taken place at Sobibór since 2007, searches for human remains have not been permitted. Recently announced plans for a new memorial that will literally seal the earth and prevent further archaeological research suggest that searches for the victims' remains will not take place now or in the foreseeable future.

5 Ibid., ch. 2.

6 S. Blau and D. H. Ubelaker, Handbook of Forensic Anthropology and Archaeology (Walnut Creek, CA: Left Coast Press, 2009).

7 J. Hunter, B. Simpson and C. Sturdy Colls, Forensic Approaches to Buried Remains (London: John Wiley \& Sons, 2013).

8 Sturdy Colls, Holocaust Archaeologies.

9 A. Kondoyanidi, 'The liberating experience: war correspondents, Red Army soldiers, and the Nazi extermination camps', The Russian Review, 69:3 (2010), 438-62.

10 United States Holocaust Memorial Museum, USHMM LIB6492; University of South Florida, 2005, Photos: Germans Confront Nazi Atrocities. URL: http://fcit.coedu.usf.edu/holocaust/resource/gallery/confront.htm (accessed 20 June 2014).

11 For examples, see H. Marcuse, Legacies of Dachau: The Uses and Abuses of a Concentration Camp 1933-2001 (Cambridge: Cambridge University Press, 2008); United States National Archives, NARA 111ADC 4594; United States Holocaust Memorial Museum, USHMM \#04724. 
12 For examples, see K. Heller and G. Simpson, The Hidden Histories of War Crimes Trials (Oxford: Oxford University Press, 2013); Central Commission for the Investigation of German Crimes in Poland, German War Crimes in Poland, vol. 1 (Warsaw: Central Commission for the Investigation of German Crimes in Poland, 1946); Polish-Soviet Extraordinary Commission for Investigating the Crimes Committed by the Germans in the Majdanek Extermination Camp in Lublin (Moscow: Foreign Languages Publishing House, 1944).

13 International Military Tribunal at Nuremberg (IMTN), Trial of the Major War Criminals before the International Military Tribunal Nuremberg 14 November 1945-1 October 1946, Nuremberg, 1947. URL: www.loc.gov/rr/ frd/Military_Law/NT_major-war-criminals.html (accessed 20 October 2007).

14 For examples in Ukraine, see P. Desbois, The Holocaust by Bullets: A Priest's Journey to Uncover the Truth behind the Murder of 1.5 Million Jews (Basingstoke: Macmillan, 2008).

15 Sturdy Colls, Holocaust Archaeologies, ch. 11.

16 For examples, see TIME, 'A mass grave raises ghosts of Romania's Holocaust past', 2010. URL: http://content.time.com/time/world/article/0,8599,2031066,00.html (accessed 12 November 2010); R. Wright, I. Hanson and J. Sterenberg, 'The archaeology of mass graves', in J. Hunter and M. Cox (eds), Forensic Archaeology: Advances in Theory and Practice (London: Routledge, 2005), pp. 137-58; J. Gross, 'Critical remarks indeed', in A. Polonsky and J. Michlic (eds), The Neighbors Respond: The Controversy over the Jedwabne Massacre in Poland (Princeton, NJ: Princeton University Press, 2004), pp. 344-70.

17 N. Márquez-Grant and L. Fibiger, The Routledge Handbook of Archaeological Human Remains and Legislation: An International Guide to Laws and Practice in the Excavation and Treatment of Archaeological Human Remains (London: Routledge, 2011).

18 For examples, see E. Susa, 'Forensic anthropology in Hungary', in M. Brickley and R. Ferlini, Forensic Anthropology: Case Studies from Europe (Springfield, IL: Charles C Thomas, 2007), pp. 203-5; N. Lisova, 'Ukraine grave site recalls Holocaust', Washington Post, 13 June 2007. URL: www.washingtonpost.com/wp-dyn/content/article/2007/06/13/ AR2007061301564.html (accessed 13 June 2007); Deutsche Welle, 'World War II euthanasia victims found in German mass grave', 29 September 2006. URL: www.dw.com/en/world-war-ii-euthanasia-victims-foundin-german-mass-grave/a-2189117 (accessed 19 January 2008).

19 P. Novick, The Holocaust in American Life (Boston: Houghton Mifflin Company, 2000).

20 R. Van der Laarse, 'Beyond Auschwitz? Europe's terrorscapes in the age of postmemory', in M. Silberman and F. Vatan (eds), Memory and Postwar Memorials: Confronting the Violence of the Past (New York: Palgrave Macmillan, 2013), p. 71; C. Sturdy Colls, 'Holocaust archaeology: archaeological approaches to landscapes of Nazi genocide and persecution', Journal of Conflict Archaeology, 7:2 (2012), 70-104; P. Hayes, 'Auschwitz, 
capital of the Holocaust: review essay', Holocaust and Genocide Studies, 17:2 (2003), 330-50.

21 For a more detailed discussion, see Sturdy Colls, Holocaust Archaeologies; Sturdy Colls, 'Holocaust archaeology'.

22 R. Harrison and J. Schofield, After Modernity: Archaeological Approaches to the Contemporary Past (Oxford: Oxford University Press, 2010).

23 A. Meiritz, 'Legends of a mass grave: the village and the Nazi labor camp', Spiegel Online, 2009. URL: www.spiegel.de/international/germany/legends-of-a-mass-grave-the-village-and-the-nazi-labor-campa-625044.html (accessed 7 May 2010).

24 D. Ofer, 'History, memory and identity: perceptions of the Holocaust in Israel', in U. Rebhun and C. Waxman (eds), Jews in Israel: Contemporary Social and Cultural Patterns (Waltham, MA: Brandeis University Press, 2004), pp. 394-417.

25 R. Bernbeck and S. Pollack, 'Grabe, Wo Du Stehst!: an archaeology of perpetrators', in Y. Hamilakis and P. Duke (eds), Archaeology and Capitalism: From Ethics to Politics (Walnut Creek, CA: Left Coast Press, 2009), pp. 217-31.

26 M. Schudrich, 'Legal issues', paper presented at the IHRA Killing Sites - Research and Remembrance Conference, Krakow, 22 January 2014; Virtual Jerusalem, 'Jewish bones found exposed in Polish town', 4 November 2014. URL: www.virtualjerusalem.com/news. php?Itemid=12613 (accessed 11 April 2014).

27 Sturdy Colls, Holocaust Archaeologies, ch. 3.

28 Schudrich, 'Legal issues'; J. Green and M. Green, Dealing with Death: A Handbook of Practices, Procedures and Law (London: Jessica Kingsley Publishers, 2006).

29 Schudrich, 'Legal issues'; Shulchan Arukh, Yoreh De'ah, 363 and 364, cited in B. Einhorn, A. Sinai, P. Hoffman and K. Felde, 'Prosecution of war criminals and violators of human rights in the United States', The Whittier Law Review, 19 (1997), 281-302.

30 European Agudas Yisroel, Jewish Cemeteries and Mass Graves in Europe: Protection and Preservation (Antwerp: European Agudas Yisroel, 2008).

31 C. Theune, 'Archaeology and remembrance: archaeological research at former concentration camps', lecture delivered at McDonald Institute, Cambridge, 19 May 2011; various personal communications; J. A. Polak, 'Exhuming their neighbors: a Halakhic inquiry', Tradition: A Journal of Orthodox Jewish Thought, 35:4 (2001), 23-43.

32 Green and Green, Dealing with Death; for more detail, see Sturdy Colls, Holocaust Archaeologies, ch. 3.

33 Green and Green, Dealing with Death.

34 Sturdy Colls, Holocaust Archaeologies, ch. 3.

35 J. Berkofsky, 'Memorial project in Poland sparks a lawsuit from Holocaust survivor', 2003. URL: www.deathcamps.org/belzec/belzeclawsuit.html (accessed 20 June 2014).

36 R. Murray, 'A mass grave raises ghosts of Romania's Holocaust past', Time, 12 November 2010. URL: http://content.time.com/time/world/ article/0,8599,2031066,00.html (accessed 12 November 2010); for more examples, see Sturdy Colls, Holocaust Archaeologies, chs 2 and 3. 
37 C. Sturdy Colls, 'Gone but not forgotten: archaeological approaches to the landscape of the former extermination camp at Treblinka, Poland, Holocaust Studies and Materials, 3 (2014), 239-89.

38 W. Chrostowski, Extermination Camp Treblinka (London: Vallentine Mitchell, 2004); Arad, Betzec, Sobibor and Treblinka.

39 See Rajzman, Samual, in IMTN, Trial of the Major War Criminals.

40 Muzeum Walki i Męczeństwa w Treblince, 2011. URL: www.treblinka. bho.pl/index.php?option $=$ com_content $\&$ task $=$ view $\&$ id $=6 \&$ Itemid $=6$ (accessed 20 January 2011).

41 Z. Łukaszkiewicz, Obóz straceń w Treblince (Warsaw: Panstwowy Instytut Wydawniczy, 1946).

42 Sturdy Colls, 'Gone but not forgotten'.

43 Sturdy Colls, Holocaust Archaeologies, ch. 3.

44 Ibid., ch. 2 and 4.

45 Sturdy Colls, 'Gone but not forgotten'.

46 Sturdy Colls, 'Gone but not forgotten'; Sturdy Colls, Holocaust Archaeologies, ch. 10.

47 S. Willenberg, Surviving Treblinka (Oxford and New York: WileyBlackwell, 1989); P. Blobel, 'Evidence by Blobel on the burning of bodies and obliterating the traces of bodies of Jews killed by the Einsatzgruppen (1947)', in Y. Arad, I. Gutman and A. Margaliot (eds), Documents on the Holocaust, Selected Sources on the Destruction of the Jews of Germany and Austria, Poland and the Soviet Union (Lincoln, NE and London: University of Nebraska Press, 1981), pp. 471-3; IMTN, Trial of the Major War Criminals, vol. 1.

48 T. Thompson, 'Heat-induced dimensional changes in bone and their consequences for forensic anthropology', Journal of Forensic Science, 50:5 (2005), 1008-15; T. Thompson, 'Recent advances in the study of burned bone and their implications for forensic anthropology', Forensic Science International, 146S (2004), 203-5.

49 R. O’Neil and M. Tregenza, 'Archaeological investigations: a review by historians', 2006. URL: www.holocaustresearchproject.org /ar/modern/ archreview.html (accessed 17 October 2007).

50 Sturdy Colls, 'Gone but not forgotten'.

51 This was while at the University of Birmingham in 2010 and Staffordshire University, 2011-15.

52 Sturdy Colls, Holocaust Archaeologies, fig. 5.10.

53 J. Fernández-Hernandez, D. González-Aguilera, P. Rodríguez-Gonzálvez and J. Mancera-Taboada, 'Image-based modelling from unmanned aerial vehicle (UAV) photogrammetry: an effective, low-cost tool for archaeological applications', Archaeometry Online, 2014. DOI:10.1111/ ARCM.12078 (accessed 18 June 2014).

54 R. Opitz and D. Cowley, Interpreting Archaeological Topography: 3D Data, Visualisation and Observation (Oxford: Oxbow Books, 2013); J. G. Liu and P. Mason, Essential Image Processing and GIS for Remote Sensing (London: John Wiley, 2009).

55 Hunter et al., Forensic Approaches to Buried Remains; M. J. Hochrein, 'An autopsy of the grave: recognizing, collecting and preserving forensic geotaphonomic evidence', in W. Haglund and M. Sorg (eds), Advances 
in Forensic Taphonomy: Method, Theory and Archaeological Perspectives (Boca Raton, FL: CRC Press, 2002), pp. 45-70.

56 Hunter et al., Forensic Approaches to Buried Remains.

57 Sturdy Colls, Holocaust Archaeologies, ch. 6.

58 P.Drewett, Field Archaeology: An Introduction (London: Routledge, 2011).

59 Hunter et al., Forensic Approaches to Buried Remains.

60 B. Bevan and T. Smekalova, 'Magnetic exploration of archaeological sites', in C. Corsi, B. Slapšak and F. Vermeulen (eds), Good Practice in Archaeological Diagnostics (New York: Springer International Publishing, 2013), pp. 133-52.

61 M. Watters and J. Hunter, 'Geophysics and burials: field experience and software development', in K. Pye and D. Croft (eds), Forensic Geoscience (London: Geological Society, 2004), pp. 21-31; L. B. Conyers, GroundPenetrating Radar for Archaeology (Lanham, MD: AltaMira Press, 2013).

62 P. Cheetham, 'Forensic geophysical survey', in J. Hunter and M. Cox (eds), Forensic Archaeology: Advances in Theory and Practice (London: Routledge, 2005), pp. 62-95.

63 H. Chapman, Landscape Archaeology and GIS (Stroud: Tempus, 2006).

64 BABAO, 'Ethics and standards', 2013. URL: www.babao.org.uk /index/ ethics-and-standards (accessed 30 March 2014); Hunter et al., Forensic Approaches to Buried Remains; M. Cox, A. Flavel, I. Hanson, J. Laver and R. Wessling, The Scientific Investigation of Mass Graves (Cambridge: Cambridge University Press, 2013); J. McKinley and C. Roberts, 'Excavation and post-excavation treatment of cremated and inhumed human remains', Technical Paper 13 (Reading: Institute of Field Archaeologists, 1993).

65 X. Mallet, T. Blytheand R. Berry, Advances in Forensic Human Identification (Boca Raton, FL: CRC Press, 2014); Interpol, 'Disaster victim identification guide', 2014. URL: www.interpol.int/INTERPOL-expertise/ Forensics/DVI-Pages/DVI-guide (accessed 21 October 2015); S. Byers, Introduction to Forensic Anthropology (London: Routledge, 2010).

66 Sturdy Colls, Holocaust Archaeologies; Sturdy Colls, 'Holocaust archaeology'.

67 Sturdy Colls, Holocaust Archaeologies; Sturdy Colls, 'Gone but not forgotten'.

68 Sturdy Colls, Holocaust Archaeologies, ch. 6.

69 R. Wright, 'Where are the bodies?: In the ground', The Public Historian, 32:1 (2010), 96-107.

70 C. Mattogno and J. Graf, Treblinka: Extermination Camp or Transit Camp? (Chicago: Theses \& Dissertations Press, 2004).

71 V. Grossman, The Hell Called Treblinka (CreateSpace Independent Publishing Platform, 2014); R. Auerbach, 'In the fields of Treblinka', in A. Donat (ed.), The Death Camp Treblinka: A Documentary (New York: Schocken Books, 1979), pp. 19-73.

72 E. Marchi, 'Methods developed to identify victims of the World Trade Center Disaster', American Laboratory, 2004. URL: www.iscpubs.com/ articles/index.php?3-al_all-al/a0403mar.pdf (accessed 12 June 2006).

73 Sturdy Colls, Holocaust Archaeologies, ch. 10.

74 M. Jasinski, A. Ossowski and K. Szwagrzyk, 'Give Them Back Their Names and Faces: competing memories and victims of communism in Poland 1939-1956, paper presented at the Competing Memories Conference, 29 October 2013, Amsterdam. 


\section{Bibliography}

Arad, Y., Betzec, Sobibor and Treblinka: The Operation Reinhard Death Camps (Bloomington and Indianapolis: Indiana University Press, 1999)

Auerbach, R., 'In the fields of Treblinka', in A. Donat (ed.), The Death Camp Treblinka: A Documentary (New York: Schocken Books, 1979), pp. 19-73

BABAO, 'Ethics and standards', 2013. URL: www.babao.org.uk /index/ ethics-and-standards (accessed 30 March 2014)

Berkofsky, J., 'Memorial project in Poland sparks a lawsuit from Holocaust survivor', 2003. URL: www.deathcamps.org/belzec/belzeclawsuit.html (accessed 20 June 2014)

Bernbeck, R. and S. Pollack, 'Grabe, Wo Du Stehst!: an archaeology of perpetrators', in Y. Hamilakis and P. Duke (eds), Archaeology and Capitalism: From Ethics to Politics (Walnut Creek, CA: Left Coast Press, 2009), pp. 217-31

Bevan, B. and T. Smekalova, 'Magnetic exploration of archaeological sites', in C. Corsi, B. Slapšak and F. Vermeulen (eds), Good Practice in Archaeological Diagnostics (New York: Springer International Publishing, 2013), pp. 133-52

Blau, S. and D. H. Ubelaker, Handbook of Forensic Anthropology and Archaeology (Walnut Creek, CA: Left Coast Press, 2009)

Blobel, P., 'Evidence by Blobel on the burning of bodies and obliterating the traces of bodies of Jews killed by the Einsatzgruppen (1947)', in Y. Arad, I. Gutman and A. Margaliot (eds), Documents on the Holocaust: Selected Sources on the Destruction of the Jews of Germany and Austria, Poland and the Soviet Union (Lincoln, NE and London: University of Nebraska Press, 1981), pp. 471-3

Byers, S., Introduction to Forensic Anthropology (London: Routledge, 2010)

Central Commission for the Investigation of German Crimes in Poland, German War Crimes in Poland, vol. 1 (Warsaw: Central Commission for the Investigation of German Crimes in Poland, 1946)

Chapman, H., Landscape Archaeology and GIS (Stroud: Tempus, 2006)

Cheetham, P., 'Forensic geophysical survey', in J. Hunter and M. Cox (eds), Forensic Archaeology: Advances in Theory and Practice (London: Routledge, 2005), pp. 62-95

Chrostowski, W., Extermination Camp Treblinka (London: Vallentine Mitchell, 2004)

Conyers, L. B., Ground-Penetrating Radar for Archaeology (Lanham, MD: AltaMira Press, 2013)

Cox, M., A. Flavel, I. Hanson, J. Laver and R. Wessling, The Scientific Investigation of Mass Graves (Cambridge: Cambridge University Press, 2013)

Desbois, P., The Holocaust by Bullets: A Priest's Journey to Uncover the Truth behind the Murder of 1.5 Million Jews (Basingstoke: Macmillan, 2008)

Deutsche Welle, 'World War II euthanasia victims found in German mass grave', 29 September 2006. URL: www.dw.com/en/world-war-iieuthanasia-victims-found-in-german-mass-grave/a-2189117 (accessed 19 January 2008)

Drewett, P., Field Archaeology: An Introduction (London: Routledge, 2011) 
Einhorn, B., A. Sinai, P. Hoffman and K. Felde, 'Prosecution of war criminals and violators of human rights in the United States', The Whittier Law Review, 19 (1997), 281-302

European Agudas Yisroel, Jewish Cemeteries and Mass Graves in Europe: Protection and Preservation (Antwerp: European Agudas Yisroel, 2008)

Fernández-Hernandez, J., D. González-Aguilera, P. Rodríguez-Gonzálvez and J. Mancera-Taboada, 'Image-based modelling from unmanned aerial vehicle (UAV) photogrammetry: an effective, low-cost tool for archaeological applications', Archaeometry Online, 2014. DOI:10.1111/ ARCM.12078 (accessed 18 June 2014)

Green, J. and M. Green, Dealing with Death: A Handbook of Practices, Procedures and Law (London: Jessica Kingsley Publishers, 2006)

Gross, J., 'Critical remarks indeed', in A. Polonsky and J. Michlic (eds), The Neighbors Respond: The Controversy over the Jedwabne Massacre in Poland (Princeton, NJ: Princeton University Press, 2004), pp. 344-70

Grossman, V., The Hell Called Treblinka (CreateSpace Independent Publishing Platform, 2014)

Harrison, R. and J. Schofield, After Modernity: Archaeological Approaches to the Contemporary Past (Oxford: Oxford University Press, 2010)

Hayes, P., 'Auschwitz, capital of the Holocaust: review essay', Holocaust and Genocide Studies, 17:2 (2003), 330-50

Heller, K. and G. Simpson, The Hidden Histories of War Crimes Trials (Oxford: Oxford University Press, 2013)

Hochrein, M. J., 'An autopsy of the grave: recognizing, collecting and preserving forensic geotaphonomic evidence', in W. Haglund and M. Sorg (eds), Advances in Forensic Taphonomy: Method, Theory and Archaeological Perspectives (Boca Raton, FL: CRC Press, 2002), pp. $45-70$

Hunter, J., B. Simpson and C. Sturdy Colls, Forensic Approaches to Buried Remains (London: John Wiley \& Sons, 2013)

IMTN (International Military Tribunal at Nuremberg), Trial of the Major War Criminals before the International Military Tribunal Nuremberg 14 November 1945-1 October 1946, Nuremberg, 1947. URL: www.loc. gov/rr/frd/Military_Law/NT_major-war-criminals.html (accessed 20 October 2007)

Jasinski, M., A. Ossowski and K. Szwagrzyk, 'Give Them Back Their Names and Faces: competing memories and victims of communism in Poland 1939-1956', paper presented at the Competing Memories Conference, 29 October 2013, Amsterdam

Kondoyanidi, A., 'The liberating experience: war correspondents, Red Army soldiers, and the Nazi extermination camps', The Russian Review, 69:3 (2010), 438-62

Lisova, N., 'Ukraine grave site recalls Holocaust', Washington Post, 13 June 2007. URL: www.washingtonpost.com/wp-dyn/content/article/2007/ 06/13/AR2007061301564.html (accessed 13 June 2007)

Liu, J. G. and P. Mason, Essential Image Processing and GIS for Remote Sensing (London: John Wiley, 2009) 
Łukaszkiewicz, Z., Obóz straceń w Treblince (Warsaw: Panstwowy Instytut Wydawniczy, 1946)

McKinley, J. and C. Roberts, 'Excavation and post-excavation treatment of cremated and inhumed human remains', Technical Paper 13 (Reading: Institute of Field Archaeologists, 1993)

Mallet, X., T. Blythe and R. Berry, Advances in Forensic Human Identification (Boca Raton, FL: CRC Press, 2014)

Marchi, E., 'Methods developed to identify victims of the World Trade Center Disaster', American Laboratory, 2004. URL: www.iscpubs. com/articles/index.php?3-al_all-al/a0403mar.pdf (accessed 12 June 2006)

Marcuse, H., Legacies of Dachau: The Uses and Abuses of a Concentration Camp 1933-2001 (Cambridge: Cambridge University Press, 2008)

Márquez-Grant, N. and L. Fibiger, The Routledge Handbook of Archaeological Human Remains and Legislation: An International Guide to Laws and Practice in the Excavation and Treatment of Archaeological Human Remains (London: Routledge, 2011)

Mattogno, C. and J. Graf, Treblinka: Extermination Camp or Transit Camp? (Chicago: Theses \& Dissertations Press, 2004)

Meiritz, A., 'Legends of a mass grave: the village and the Nazi labor camp', Spiegel Online, 2009. URL: www.spiegel.de/international/germany/ legends-of-a-mass-grave-the-village-and-the-nazi-labor-camp-a625044.html (accessed 7 May 2010)

Murray, R., 'A mass grave raises ghosts of Romania's Holocaust past', Time, 12 November 2010. URL: http://content.time.com/time/world/article/ 0,8599,2031066,00.html (accessed 12 November 2010)

Muzeum Walki i Męczeństwa w Treblince, 2011. URL: www.treblinka. bho.pl/index.php?option=com_content \&task=view \&id $=6 \&$ Itemid $=6$ (accessed 20 January 2011)

Novick, P., The Holocaust in American Life (Boston: Houghton Mifflin Company, 2000)

Ofer, D., 'History, memory and identity: perceptions of the Holocaust in Israel', in U. Rebhun and C. Waxman (eds), Jews in Israel: Contemporary Social and Cultural Patterns (Waltham, MA: Brandeis University Press, 2004), pp. 394-417

O'Neil, R. and M. Tregenza, 'Archaeological investigations: a review by historians', 2006. URL: www.holocaustresearchproject.org /ar/modern/ archreview.html (accessed 17 October 2007)

Opitz, R. and D. Cowley, Interpreting Archaeological Topography: 3D Data, Visualisation and Observation (Oxford: Oxbow Books, 2013)

Polak, J. A., 'Exhuming their neighbors: a Halakhic inquiry', Tradition: A Journal of Orthodox Jewish Thought, 35:4 (2001), 23-43

Polish-Soviet Extraordinary Commission for Investigating the Crimes Committed by the Germans in the Majdanek Extermination Camp in Lublin (Moscow: Foreign Languages Publishing House, 1944)

Schudrich, M., 'Legal issues', paper presented at the IHRA Killing Sites Research and Remembrance Conference, 22 January 2014, Krakow 
Sturdy Colls, C., 'Holocaust archaeology: archaeological approaches to landscapes of Nazi genocide and persecution', Journal of Conflict Archaeology, 7:2 (2012), 70-104

Sturdy Colls, C., 'Gone but not forgotten: archaeological approaches to the landscape of the former extermination camp at Treblinka, Poland, Holocaust Studies and Materials, 3 (2014), 239-89

Sturdy Colls, C., Holocaust Archaeologies: Approaches and Future Directions (New York: Springer, 2015)

Susa, E., 'Forensic anthropology in Hungary', in M. Brickley and R. Ferlini (eds), Forensic Anthropology: Case Studies from Europe (Springfield, IL: Charles C Thomas, 2007)

Theune, C., 'Archaeology and remembrance: archaeological research at former concentration camps', lecture delivered at McDonald Institute, Cambridge, 19 May 2011

Thompson, T., 'Recent advances in the study of burned bone and their implications for forensic anthropology'. Forensic Science International, 146S (2004), 203-5

Thompson, T., 'Heat-induced dimensional changes in bone and their consequences for forensic anthropology', Journal of Forensic Science, 50:5 (2005), 1008-15

TIME, 'A mass grave raises ghosts of Romania's Holocaust past', 2010. URL: http://content.time.com/time/world/article/0,8599,2031066,00.html (accessed 12 November 2010)

Van der Laarse, R., 'Beyond Auschwitz? Europe's terrorscapes in the age of postmemory', in M. Silberman and F. Vatan (eds), Memory and Postwar Memorials: Confronting the Violence of the Past (New York: Palgrave Macmillan, 2013)

Virtual Jerusalem, 'Jewish bones found exposed in Polish town', 4 November 2014. URL: www.virtualjerusalem.com/news.php?Itemid=12613 (accessed 11 April 2014)

Watters, M. and J. Hunter, 'Geophysics and burials: field experience and software development', in K. Pye and D. Croft (eds), Forensic Geoscience (London: Geological Society, 2004), pp. 21-31

Willenberg, S., Surviving Treblinka (Oxford and New York: Wiley-Blackwell, 1989)

Wright, R., 'Where are the bodies?: In the ground', The Public Historian, 32:1 (2010), 96-107

Wright, R., I. Hanson and J. Sterenberg, 'The archaeology of mass graves', in J. Hunter and M. Cox (eds), Forensic Archaeology: Advances in Theory and Practice (London: Routledge, 2005), pp. 137-58 